\title{
Modulation of Inducible Nitric Oxide Synthase Expression in LPS-Stimulated BV-2 Microglia by Prenylated Chalcones from Cullen corylifolium (L.) Medik. through Inhibition of I- $\kappa \mathrm{B} \alpha$ Degradation
}

\author{
Do Hee Kim ${ }^{1}$, Hua Li ${ }^{1}$, Yeong Eun Han ${ }^{1}$, Ji Hye Jeong ${ }^{1}$, Hwa Jin Lee ${ }^{2, *}$ and Jae-Ha Ryu ${ }^{1, *}$ \\ 1 Research Institute of Pharmaceutical Sciences, College of Pharmacy, Sookmyung Women's University, \\ Seoul 04310, Korea; kdhkazan3@naver.com (D.H.K.); cooldog227@hotmail.com (H.L.); \\ thdd11428@naver.com (Y.E.H.); jjh4415@naver.com (J.H.J.) \\ 2 Department of Natural Medicine Resources, Semyung University, Jecheon 27136, Korea \\ * Correspondence: hwalee@semyung.ac.kr (H.J.L.); ryuha@sookmyung.ac.kr (J.-H.R.); \\ Tel.: +82-43-649-1682 (H.J.L.); +82-2-710-9568 (J.-H.R.)
}

Received: 8 November 2017; Accepted: 28 December 2017; Published: 4 January 2018

\begin{abstract}
The overproduction of nitric oxide $(\mathrm{NO})$ and prostaglandin $\mathrm{E}_{2}\left(\mathrm{PGE}_{2}\right)$ by microglia may cause neurodegenerative diseases, such as Alzheimer's disease and Parkinson's disease. From the activity-guided purification of Cullen corylifolium (L.) Medik. (syn. Psoralea corylifolia L.), three prenylated chalcones were identified: isobavachalcone (1), bavachromene (2), and kanzonol $B$ (3). These prenylated chalcones showed concentration-dependent inhibitory effects on NO and $\mathrm{PGE}_{2}$ production in lipopolysaccharide (LPS)-activated microglia. Western blotting and RT-PCR analysis demonstrated that these prenylchalcones reduced the expression of protein and mRNA of inducible nitric oxide synthase (iNOS) and cyclooxygenase-2 (COX-2) in LPS-activated microglia. Furthermore, three prenylated chalcones blocked the inhibitory- $\mathrm{B} \mathrm{B} \alpha(\mathrm{I}-\mathrm{k} \mathrm{B} \alpha)$ degradation and down-regulated nuclear factor $\mathrm{kB}$ (NF-kB) level of nucleus in LPS-stimulated BV-2 microglia. Therefore, these prenylated chalcones from Psoralea corylifolia may be beneficial for the treatment of neuro-inflammatory diseases by modulating iNOS and COX-2 expressions in activated microglial cells.
\end{abstract}

Keywords: Cullen corylifolium; Psoralea corylifolia; prenylated chalcone; nitric oxide; inducible nitric oxide synthase; prostaglandin E2; inhibitory- $\mathrm{kB} \alpha$

\section{Introduction}

Microglia, an innate immune cell and resident phagocyte in the central nervous system (CNS), plays an active role in CNS homeostasis, infection and pathogen defense. Activated microglia produce pro-inflammatory and neuro-toxic materials such as nitric oxide (NO), prostaglandins (PGs) and superoxide anion [1]. These mediators are involved in the brain injuries and neurodegenerative diseases including Alzheimer's disease, amyotrophic lateral sclerosis and Parkinson's disease [2,3]. NO can be produced by three isoforms of nitric oxide synthase (NOS) such as neuronal NOS (nNOS), endothelial NOS (eNOS) and inducible NOS (iNOS) [4]. The nNOS and eNOS, constitutive NOS (cNOS), release small amounts of NO and maintain physiological functions, while iNOS, inducible form, by lipopolysaccharide (LPS) and various cytokines, produces micromolar levels of NO [5]. Many reports have shown that the iNOS and a large amount of NO produced by activated microglia contribute to the progress of neurodegenerative diseases [6]. $\mathrm{PGE}_{2}$, the other inflammatory mediator, is synthesized by a cyclooxygenase (COX)-dependent pathway [7]. COX enzyme consists of at least two isoforms, namely cyclooxygenase- 1 (COX-1) and cyclooxygenase-2 (COX-2). The COX-2 form is 
induced by pro-inflammatory effectors such as cytokines and LPS and leads to an elevated production of $\mathrm{PGE}_{2}$, whereas COX-1 is constitutively expressed under normal conditions [8]. Therefore, inhibition of pro-inflammatory enzymes may have therapeutic effects for the treatment of diverse diseases $[9,10]$. The seeds of Cullen corylifolium (L.) Medik. (syn. Psoralea corylifolia L.) (Leguminosae) have been used traditionally for treatment of gynaecological bleeding, vitiligo and psoriasis. Its seeds were reported to contain coumarins, flavonoids and meroterpene phenols, and some of them exhibited anti-neuroinflammatory, anti-bacterial, anti-tumor, broadening coronary artery and estrogen-like activities [11-17]. The present study reports that prenylated chalcones from the extracts of $C$. corylifolium display inhibitory activities on $\mathrm{NO}$ and $\mathrm{PGE}_{2}$ production in LPS-activated microglia, and discloses the underlying mechanism for their biological activities.

\section{Results and Discussion}

The prenylated chalcones 1-3 were isolated from Cullen corylifolium by activity-guided purification. Their chemical structures were elucidated by the analysis of their mass and NMR spectral data (Supplementary Materials, Figures S1-S15). Isobavachalcone (1) [18,19], has been predominantly isolated from plants of Leguminosae and Moraceae families [20] and has a prenyl moiety, while bavachromene (2) [12,21] and kanzonol B (3) [22], have cyclized prenyl moieties that form a pyrano ring in the chalcone skeleton (Figure 1).

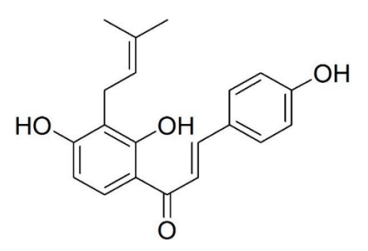

1

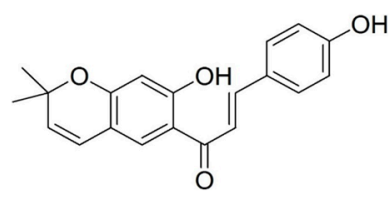

2

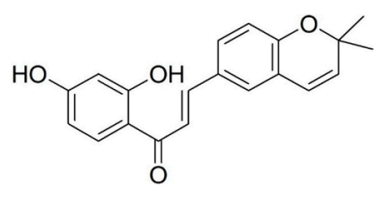

3

Figure 1. The chemical structures of compounds 1-3 from Cullen corylifolium.

Isolated compounds showed concentration-dependent inhibitory activity on NO production in LPS-activated microglia (Figure 2a). Their $\mathrm{IC}_{50}$ values were $1.6 \pm 0.11 \mu \mathrm{M}(\mathbf{1}), 2.4 \pm 0.18 \mu \mathrm{M}(\mathbf{2})$, and $2.2 \pm 0.21 \mu \mathrm{M}(3)$, respectively. Compounds 1-3 did not affect cell viability at the tested concentrations (data not shown). In particular, the chalcone 1 characterized by the presence of open chain prenyl group showed more potent inhibitory activity on NO production than chalcones 2 and 3 containing cyclic pyranoprenyl groups.

$\mathrm{NO}$ combines with superoxide anion and is transformed into peroxynitrite $\left(\mathrm{ONOO}^{-}\right)$, an inflammatory mediator with strong oxidizing properties [23]. Peroxynitrite is responsible for the pathogenesis of neuronal diseases such as neuronal ageing and Alzheimer's disease [24]. To examine whether prenylated chalcones 1-3 could remove peroxynitrite, its scavenging was measured in a cell free assay system by observing the fluorescence of the oxidized substance of dihydrorhodamine 123 (DHR 123) by authentic peroxynitrite [25]. Compounds $\mathbf{1}-\mathbf{3}$ showed potent $\mathrm{ONOO}^{-}$scavenging activity $(93.6 \%, 76.8 \%$ and $51.2 \%$ at $20 \mu \mathrm{M}$, Figure $2 \mathrm{~b})$, respectively, while penicillamine $(20 \mu \mathrm{M})$, a positive control, displayed $74.9 \%$ scavenging activity. Prenylated chalcone 1 showed more efficient scavenging activity compared with cyclic pyranoprenyl group-containing chalcones $\mathbf{2}$ and $\mathbf{3}$. Taken together, these results show that active compounds 1-3 downregulate the overproduction of $\mathrm{NO}$ in activated microglial cells and also significantly eliminate the $\mathrm{ONOO}^{-}$, which suggest that compounds 1-3 might prevent the neuro-inflammatory response.

Prostaglandin $\mathrm{E}_{2}\left(\mathrm{PGE}_{2}\right)$ is a critical inflammatory mediator, which is a major material produced by COX-2 [7]. To determine whether compounds 1-3 inhibit $\mathrm{PGE}_{2}$ production in LPS-induced BV-2 microglia, we examined the $\mathrm{PGE}_{2}$ accumulation using $\mathrm{PGE}_{2}$ enzyme immunoassay (EIA). Compounds 1-3 $(5 \mu \mathrm{M})$ showed $90 \%, 78 \%$ and $54 \%$ inhibition of PGE $_{2}$ production, 
respectively (Figure 2c). The results showed that LPS enhanced the production of $\mathrm{PGE}_{2}$ in BV-2 cells and prenylated chalcones 1-3 significantly suppressed the $\mathrm{PGE}_{2}$ synthesis. Furthermore, prenyl chalcone 1 treatment showed lower levels of $\mathrm{PGE}_{2}$ synthesis than 2 and 3 with cyclic pyranoprenyl chalcone groups.

(a)

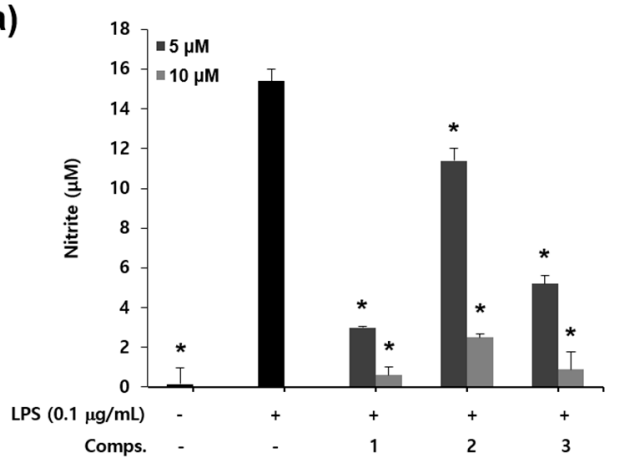

(b)

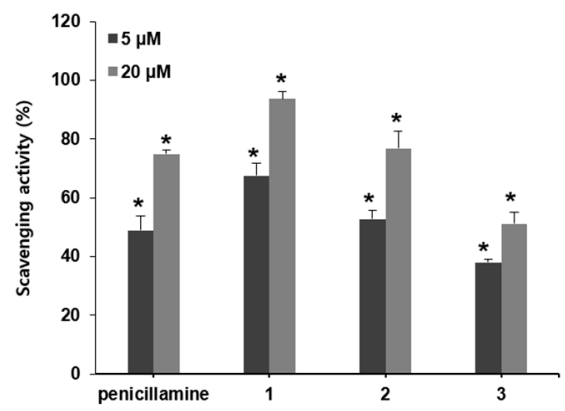

(c)

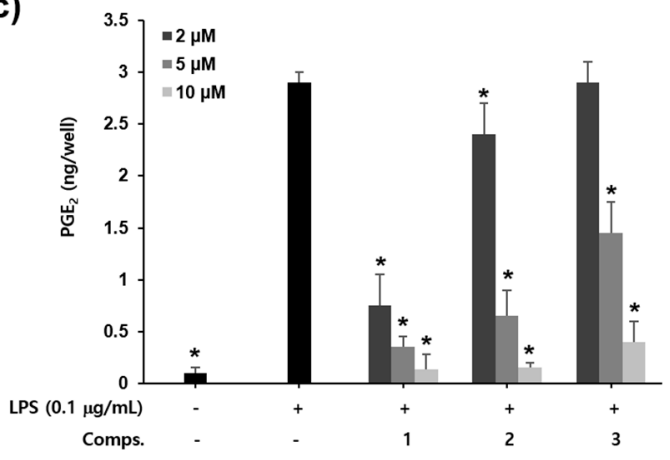

Figure 2. The effects of compounds 1-3 on pro-inflammatory and neuro-toxic mediators. (a) Inhibitory effects of compounds 1-3 on NO production in LPS-stimulated BV-2 microglia. The amount of NO in culture medium was measured using Griess reagents; $(\mathbf{b})$ Peroxynitrite $\left(\mathrm{ONOO}^{-}\right)$scavenging activity of compounds 1-3 in vitro cell free system. The level of $\mathrm{ONOO}^{-}$was measured by detecting the oxidation of DHR123 as experimental section. Penicillamine was used as a positive control; (c) Inhibitory effects of compounds 1-3 on $\mathrm{PGE}_{2}$ production in LPS-stimulated BV-2 microglia. The levels of $\mathrm{PGE}_{2}$ were determined by the enzyme immunoassay. The values are expressed as the means \pm S.D. of three experiments. ${ }^{*} p<0.05$.

To reveal the underlying mechanism of compounds for the inhibition of $\mathrm{NO}$ and $\mathrm{PGE}_{2}$ production in LPS-treated microglia, protein and mRNA levels of iNOS and COX-2 were investigated by western blot and RT-PCR analysis. As shown in Figure 3a, compounds 1-3 (5 $\mu \mathrm{M})$ suppressed the iNOS protein expression in BV-2 microglia cells, whereas LPS markedly enhanced the protein levels of iNOS. Compounds 1 and 2 also downregulated COX-2 protein expression compared with LPS control, while compound $\mathbf{3}$ was not effective. Furthermore, compounds 1-3 attenuated the iNOS and COX-2 mRNA levels whereas LPS treatment distinctly up-regulated their mRNA levels (Figure 3b). The suppressive effects of compounds 1-3 on iNOS expression level were not exactly parallel with the COX-2 level. These results suggest that compounds 1-3 inhibit the transcriptional expression of LPS-induced iNOS and COX-2.

Next we examined the effect of compounds 1-3 on nuclear factor $\mathrm{kB}$ (NF- $\mathrm{kB}$ ) that regulates the expression of pro-inflammatory enzymes such as iNOS and COX-2 [26]. NF- $\mathrm{kB}$, a transcription factor complex of p50 and p65 subunits, is found in cytoplasm as an inactive p50/p65 dimer. Inhibitor $\kappa B(I-\kappa B)$ physically combines with p50/p65 dimer to suppress the NF- $\kappa B$ activation in normal conditions [27]. In response to pro-inflammatory stimuli, I- $\mathrm{kB}$ is rapidly degraded to 
release p50/p65. Free p50/p65 moves to the nucleus and induces the expression of pro-inflammatory genes [28]. To disclose the molecular mechanism for their inhibitory effect on pro-inflammatory enzyme expressions, we investigated whether compounds 1-3 affect the LPS-induced I- $k \mathrm{~B} \alpha$ degradation and nuclear level of p65 subunit of NF-kB. As shown in Figure 3c, compounds 1-3 suppressed the LPS-induced degradation of I- $\mathrm{kB} \alpha$ and decreased the level of nuclear p65 by the treatment of 1-3 (at $5 \mu \mathrm{M}$ ). In addition, compound $\mathbf{1}$ with presence of non-cyclic prenyl moiety most potently suppressed degradation of I- $\mathrm{B} \mathrm{B} \alpha$ and nuclear level of NF- $\mathrm{kB}$ than those of cyclic pyranoprenyl chalcones 2 and 3 . Moreover, the results of isobavachalcone (1) showed concurrence with previous reports that showed its potentials for anti-inflammatory drug and therapeutic candidate against Parkinson's disease by suppressing the TLR agonist induced-iNOS expression in RAW 264.7 macrophages and inhibiting the NF- $\kappa B$ activation in BV-2 microglia $[29,30]$.

(a)

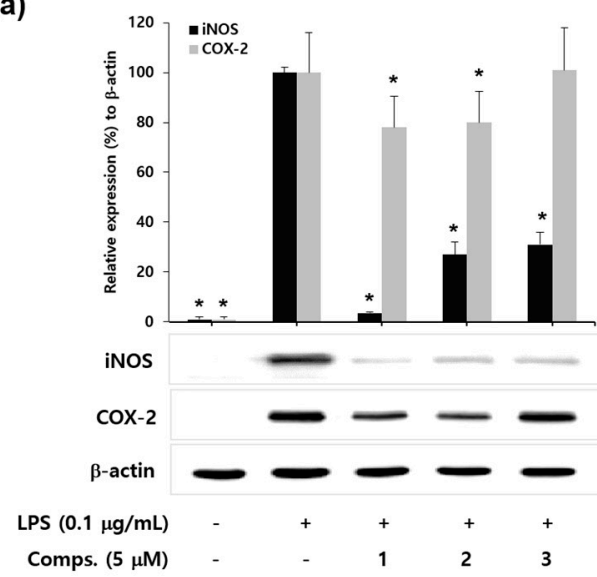

(b)

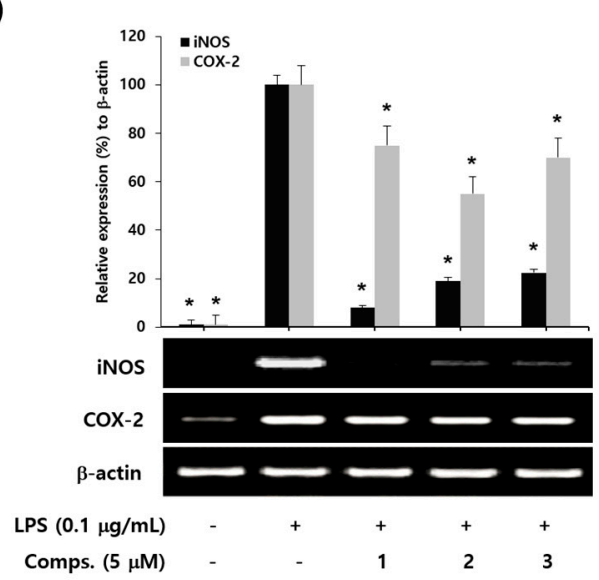

(c)

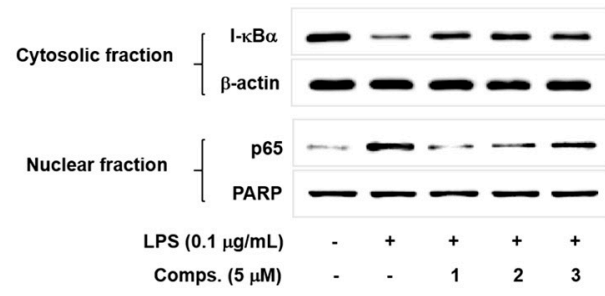

Figure 3. The effects of compounds 1-3 on LPS-induced iNOS/COX-2 expression and I-kB $\alpha$ degradation in BV-2 microglia. (a) The effects of compounds 1-3 on LPS-stimulated iNOS and COX-2 protein expression. The protein levels were determined by Western blot analysis. The relative intensity of iNOS/COX-2 to $\beta$-actin bands was measured by densitometry. The values represent the means \pm S.D. of three experiments. * $p<0.05$; (b) The effects of compounds 1-3 on LPS-stimulated iNOS and COX-2 mRNA expression. The mRNA levels were examined by RT-PCR analysis. The relative intensity of iNOS/COX-2 to $\beta$-actin bands was measured by densitometry. The values represent the means \pm S.D. of three experiments. ${ }^{*} p<0.05$; (c) The effects of compounds 1-3 on LPS-induced I- $\kappa \mathrm{B} \alpha$ degradation and p65 level in nucleus of BV-2 microglia. Cells were treated with compounds 1-3 for 30 min prior to activation of LPS $(0.1 \mu \mathrm{g} / \mathrm{mL})$. After 15 min treatment of LPS, cytosolic I- $\kappa \mathrm{B} \alpha$ and nuclear p65 were analyzed by western blot. Images are the representative of three independent experiments that show similar results.

Taken together, these results demonstrate that prenyated chalcones $\mathbf{1}-\mathbf{3}$ reduce the degradation of $\mathrm{I}-\mathrm{kB} \alpha$ and nuclear level of NF-kB in LPS-stimulated BV-2 microglia.

In summary, we isolated three prenylated chalcone derivatives from Cullen corylifoliumisobavachalcone (1), bavachromene (2) and kanzonol B (3) - as potent NO inhibitors in LPS-activated microglia. They also suppress $\mathrm{PGE}_{2}$ production and down-regulate the expression of iNOS and COX-2 
through suppressing I- $\mathrm{kB} \alpha$ degradation in LPS-activated microglia. These results imply that prenylated chalcones from Cullen corylifolium could be used for the treatment of neuro-inflammatory diseases.

\section{Materials and Methods}

\subsection{General Information}

1D and 2D NMR spectra were obtained on a VARIAN UNITY INOVA 400 spectrometer (Varian, Palo Alto, CA, USA). Mass spectra were determined on a JEOL JMS-AX505WA mass spectrometer (Tokyo, Japan). Column chromatography was carried out over silica gel (40-60 $\mu \mathrm{m}$, Merck, Kenilworth, NJ, USA) and LiChroprep RP-C18 (40-60 $\mu \mathrm{m}$, Merck). HPLC (high performance liquid chromatography) was carried out on a Waters 1525 system (Miliford, MA, USA) using reverse-phase column (ODS-2, $5 \mu \mathrm{m}, 4.6 \times 15 \mathrm{~cm}$, GL Science, Seoul, Korea). Fractions obtained from column chromatography were monitored by thin layer chromatography (TLC) (RP-C18 $\mathrm{F}_{254 S}$ and silica gel $60 \mathrm{~F}_{254}$, Merck).

\subsection{Plant Material, Extraction and Isolation}

The seeds of Cullen corylifolium (L.) Medik. (syn. Psoralea corylifolia L.) were purchased from the Kyungdong Hearbal Market in Seoul, Korea. Authentication of plant material was carried out by Prof. K.S. Yang at College of Pharmacy, Sookmyung Women's University. A voucher specimen (No. SPH 13003) was deposited in the herbarium of Sookmyung Women's University. The air-dried plant materials $(8.8 \mathrm{~kg})$ were washed with $10 \mathrm{~L}$ of $n$-hexane to remove fat. The remained materials were extracted with $10 \mathrm{~L}$ of methanol three times at room temperature for $24 \mathrm{~h}$. The concentrated alcoholic extracts $(1.6 \mathrm{~kg}$ ) were suspended in water and successively partitioned with $20 \%$ hexane and EtOAc. The activity-guided chromatography for EtOAc soluble fraction was performed to purify the active principles. The EtOAc fraction (153.83 g) was subjected to silica gel column chromatography eluting with $n$-hexane:EtOAc gradient system $(4: 1 \rightarrow 1: 1)$ and 19 fractions were collected. Fraction 7 was further chromatographed on a RP-C18 column with a gradient elution of $\mathrm{MeOH}(50 \% \rightarrow 100 \%)$ to afford 13 sub-fractions. Sub-fraction 7-13 was rechromatographed on silica gel with $\mathrm{CH}_{2} \mathrm{Cl}_{2}$ : $\mathrm{EtOAc}$ isocratic system (100:1) to afford five sub-fractions. Each of subfraction 7-13-2 and 7-13-4 was further purified by a silica gel column with $n$-hexane:acetone gradient system $(10: 1 \rightarrow 1: 1)$ as eluents to yield compound $2(17 \mathrm{mg})$ and compound $3(6 \mathrm{mg})$. Fraction 12 was chromatographed on silica gel with $n$-hexane:EtOAc (contained 10\% isopropanol) gradient system $(20: 1 \rightarrow 1: 3)$ to afford 14 subfractions. Subfraction 12-6 was rechromatographed on a silica gel column eluting with $n$-hexane:EtOAc (contained 10\% isopropanol) gradient system (30:1 $\rightarrow$ 1:1) and then fraction 12-6-7 was further purified by a silica gel column with $\mathrm{CHCl}_{3}: \mathrm{MeOH}$ gradient system $(100: 1 \rightarrow 20: 1)$ to yield compound $\mathbf{1}(12 \mathrm{mg})$. The purity of compounds was confirmed by HPLC analysis and their ${ }^{1} \mathrm{H}-\mathrm{NMR}$ spectra. The structures of compounds were elucidated by the analysis of their corresponding mass and NMR spectroscopic data (Supplementary Materials, Figures S1-S15).

Isobavachalcone (1). ${ }^{1} \mathrm{H}-\mathrm{NMR}\left(\mathrm{CD}_{3} \mathrm{OD}, 400 \mathrm{MHz}\right) \delta: 7.82\left(1 \mathrm{H}, \mathrm{d}, J=9.2, \mathrm{H}-6^{\prime}\right), 7.77(1 \mathrm{H}, \mathrm{d}, J=15.6, \mathrm{H}-\beta)$, $7.61(1 \mathrm{H}, \mathrm{d}, J=15.6, \mathrm{H}-\alpha), 7.60(2 \mathrm{H}, \mathrm{d}, J=8.4, \mathrm{H}-2, \mathrm{H}-6), 6.84(2 \mathrm{H}, \mathrm{d}, J=8.4, \mathrm{H}-3, \mathrm{H}-5), 6.43(1 \mathrm{H}, \mathrm{d}$, $\left.J=9.2, \mathrm{H}-5^{\prime}\right), 5.23\left(1 \mathrm{H}, \mathrm{m}, \mathrm{H}-2^{\prime \prime}\right), 3.32\left(1 \mathrm{H}, \mathrm{m}, \mathrm{H}-\mathrm{-}^{\prime \prime}\right), 1.78\left(3 \mathrm{H}, \mathrm{s}, \mathrm{H}-4^{\prime \prime}\right), 1.66\left(3 \mathrm{H}, \mathrm{s}, \mathrm{H}-5^{\prime \prime}\right) .{ }^{13} \mathrm{C}-\mathrm{NMR}$ (CD $\left.{ }_{3} \mathrm{OD}, 100 \mathrm{MHz}\right)$ 8: $193.7(\mathrm{C}=\mathrm{O}), 165.2\left(\mathrm{C}-4^{\prime}\right), 163.6\left(\mathrm{C}-2^{\prime}\right), 161.5(\mathrm{C}-4), 145.3(\mathrm{C}-\beta), 131.9\left(\mathrm{C}-3^{\prime \prime}\right)$, 131.7 (C-2), 131.7 (C-6), $130.4\left(\mathrm{C}-6^{\prime}\right), 123.6\left(\mathrm{C}-2^{\prime \prime}\right), 118.6$ (C- $\left.\alpha\right), 116.9$ (C-3), 116.9 (C-5), 116.6 (C-3'), $114.5(\mathrm{C}-1), 114.5\left(\mathrm{C}-1^{\prime}\right) 108.2\left(\mathrm{C}-5^{\prime}\right), 26.0\left(\mathrm{C}-5^{\prime \prime}\right), 22.5\left(\mathrm{C}-1^{\prime \prime}\right), 17.9\left(\mathrm{C}-4^{\prime \prime}\right)$. FABMS: $m / z 325[\mathrm{M}+1]^{+}$.

Bavachromene (2). ${ }^{1} \mathrm{H}-\mathrm{NMR}\left(\mathrm{CD}_{3} \mathrm{OD}+\mathrm{CDCl}_{3}, 400 \mathrm{MHz}\right) \delta: 7.77(1 \mathrm{H}, \mathrm{d}, J=15.2, \mathrm{H}-\beta), 7.58(1 \mathrm{H}, \mathrm{s}$, H-6' $), 7.55(2 \mathrm{H}, \mathrm{d}, J=8.8, \mathrm{H}-2, \mathrm{H}-6), 7.45(1 \mathrm{H}, \mathrm{d}, J=15.2, \mathrm{H}-\alpha), 6.84(2 \mathrm{H}, \mathrm{d}, J=8.8, \mathrm{H}-3, \mathrm{H}-5)$, $6.34\left(1 \mathrm{H}, \mathrm{d}, J=10.0, \mathrm{H}-10^{\prime}\right), 6.28\left(1 \mathrm{H}, \mathrm{s}, \mathrm{H}-3^{\prime}\right), 5.59\left(1 \mathrm{H}, \mathrm{d}, J=10.0, \mathrm{H}^{\prime} 9^{\prime}\right), 1.42\left(6 \mathrm{H}, \mathrm{s}, \mathrm{H}-11^{\prime}, \mathrm{H}-12^{\prime}\right)$. ${ }^{13} \mathrm{C}-\mathrm{NMR}\left(\mathrm{CD}_{3} \mathrm{OD}+\mathrm{CDCl}_{3}, 100 \mathrm{MHz}\right) \delta: 192.8(\mathrm{C}=\mathrm{O}), 166.4\left(\mathrm{C}-4^{\prime}\right), 161.0\left(\mathrm{C}-2^{\prime}\right), 160.7(\mathrm{C}-4), 145.6(\mathrm{C}-\beta)$, 
131.3 (C-2, C-6), 129.3 (C-9'), 128.3 (C-6'), 127.0 (C-1), 121.6 (C-10'), 117.5 (C- $\alpha), 116.5$ (C-3, C-5), $114.8\left(\mathrm{C}-1^{\prime}\right), 114.3\left(\mathrm{C}-5^{\prime}\right), 104.8\left(\mathrm{C}-3^{\prime}\right), 78.6\left(\mathrm{C}-8^{\prime}\right) 28.8\left(\mathrm{C}-11^{\prime}, \mathrm{C}-12^{\prime}\right)$. FABMS: $m / z 323[\mathrm{M}+1]^{+}$.

Kanzonol B (3). ${ }^{1} \mathrm{H}-\mathrm{NMR}\left(\mathrm{CD}_{3} \mathrm{OD}+\mathrm{CDCl}_{3}, 400 \mathrm{MHz}\right) \delta: 7.84\left(1 \mathrm{H}, \mathrm{d}, J=8.8, \mathrm{H}-6^{\prime}\right), 7.73(1 \mathrm{H}, \mathrm{d}$, $J=15.2, \mathrm{H}-\beta), 7.48(1 \mathrm{H}, \mathrm{d}, J=15.2, \mathrm{H}-\alpha), 7.43(1 \mathrm{H}, \mathrm{dd}, J=2.0,8.4, \mathrm{H}-2), 7.31(1 \mathrm{H}, \mathrm{d}, J=2.4, \mathrm{H}-6)$, $6.77(1 \mathrm{H}, \mathrm{d}, J=8.4, \mathrm{H}-3), 6.41\left(1 \mathrm{H}, \mathrm{dd}, J=2.4,8.8, \mathrm{H}-5^{\prime}\right), 6.37(1 \mathrm{H}, \mathrm{d}, J=9.6, \mathrm{H}-10), 6.32(1 \mathrm{H}, \mathrm{d}, J=2.4$, $\left.\mathrm{H}-3^{\prime}\right), 5.69(1 \mathrm{H}, \mathrm{d}, J=9.6, \mathrm{H}-9), 1.43(6 \mathrm{H}, \mathrm{s}, \mathrm{H}-11, \mathrm{H}-12) .{ }^{13} \mathrm{C}-\mathrm{NMR}\left(\mathrm{CD}_{3} \mathrm{OD}+\mathrm{CDCl}_{3}, 100 \mathrm{MHz}\right) \delta$ : $192.7(\mathrm{C}=\mathrm{O}), 166.6\left(\mathrm{C}-2^{\prime}\right), 165.5\left(\mathrm{C}-4^{\prime}\right), 156.2(\mathrm{C}-4), 144.7(\mathrm{C}-\beta), 132.6\left(\mathrm{C}-6^{\prime}\right), 132.0(\mathrm{C}-9), 130.7$ (C-2), 128.3 (C-1), 127.2 (C-6), 122.2 (C-10), 122.1 (C-5), $118.4(\mathrm{C}-\alpha), 117.5(\mathrm{C}-3), 114.1\left(\mathrm{C}-1^{\prime}\right), 108.8\left(\mathrm{C}-5^{\prime}\right)$, $103.6\left(\mathrm{C}-3^{\prime}\right), 77.8(\mathrm{C}-8), 28.4(\mathrm{C}-11, \mathrm{C}-12)$. FABMS: $m / z 323[\mathrm{M}+1]^{+}$.

\subsection{Cell Culture}

BV-2 microglial cells (ATCC, Rockville, MD, USA) were grown in DMEM supplemented with 10\% FBS, 100 units / mL penicillin, and $100 \mu \mathrm{g} / \mathrm{mL}$ streptomycin (Life Technologies, Frederick, MD, USA). Cells were maintained at $37{ }^{\circ} \mathrm{C}$ with $5 \% \mathrm{CO}_{2}$ in a humidified atmosphere. All test concentrations of compounds showed no significant toxicity. The cell viability was determined by MTT assay.

\subsection{Measurement of Nitric Oxide Production}

BV-2 microglial cells $\left(1 \times 10^{5}\right.$ cells $/ \mathrm{mL}$ in 48 -well plate) were treated with LPS $(0.1 \mu \mathrm{g} / \mathrm{mL})$ in the absence or presence of test compounds for $20 \mathrm{~h}$. NO was measured by detecting the accumulated nitrite by Griess method. Briefly, samples $(100 \mu \mathrm{L})$ of culture media were combined with $150 \mu \mathrm{L}$ of Griess reagent ( $1 \%$ sulfanilamide, $0.1 \%$ naphthylethylene diamine in $2.5 \%$ phosphoric acid solution) and then incubated at room temperature for $10 \mathrm{~min}$. Absorbance was detected at $540 \mathrm{~nm}$ by using a microplate reader (Molecular Devices, Sunnyvale, CA, USA). The concentration of NO was determined by the sodium nitrite standard curve.

\subsection{Peroxynitrite $\left(\mathrm{ONOO}^{-}\right)$Scavenging Assay}

$10 \mu \mathrm{L}$ of test compounds were added to the reaction buffer containing $5 \mu \mathrm{M}$ dihydrorhodamine 123 (DHR 123, Molecular Probes, Eugene, OR, USA) and $100 \mu \mathrm{M}$ diethylenetriaminepentaacetic acid (DTPA). After the treatment with presence or absence (background) of native $10 \mu \mathrm{M} \mathrm{ONOO}^{-}$ (Cayman Chemical Co., Ann Arbor, MI, USA) for $5 \mathrm{~min}$, the final and background fluorescent intensities were measured. Penicillamine was used as a positive control. The fluorescence was measured at room temperature by a microplate fluorescence spectrophotometer (Spectra Max Gemini XS, Molecular Devices, Sunnyvale, CA, USA) with excitation and emission wavelength of 500 and $530 \mathrm{~nm}$, respectively. $\mathrm{ONOO}^{-}$scavenging activity (\%) of test compounds were expressed as the ratio of the decreased fluorescence to the control fluorescence. The concentration of $\mathrm{ONOO}^{-}$solution was determined spectrophotometrically $\left(\varepsilon_{302}=1670 \mathrm{M}^{-1} \mathrm{~cm}^{-1}\right)$ using Ultraspec $2000 \mathrm{UV} / \mathrm{visible}$ spectrophotometer (Pharmacia-Biotech, Cambridge, UK).

\subsection{Prostagandin E2 Assay}

To examine the effects of compounds on COX-2, cells were attached with aspirin (500 $\mu \mathrm{M})$ to inactivate the COX-1. After $2 \mathrm{~h}$, cells were washed with fresh media three times and incubated with LPS $(0.1 \mu \mathrm{g} / \mathrm{mL})$ in presence of compounds for $20 \mathrm{~h}$. The $\mathrm{PGE}_{2}$ levels in culture media were determined using enzyme immunoassay kit (Cayman Chemical) according to the manufacturer's instruction. Briefly, $50 \mu \mathrm{L}$ of supernatant of the culture medium and $50 \mu \mathrm{L} \mathrm{PGE}_{2}$ tracer were put into the $\mathrm{PGE}_{2}$ EIA plate and incubated for $18 \mathrm{~h}$ at room temperature. The wells were washed with $10 \mathrm{mM}$ phosphate buffer ( $\mathrm{pH} 7.4$ ) containing $0.05 \%$ Tween 20 . Then $200 \mu \mathrm{L}$ of Ellman's reagent was added to the well and incubated in the dark. Following the developing step, the absorbance was read at $405 \mathrm{~nm}$ by a microplate reader. A standard curve was prepared simultaneously with $\mathrm{PGE}_{2}$ standard ranging from 0.05 to $6 \mathrm{ng} / \mathrm{mL}$. 


\subsection{Western Blot Analysis}

BV-2 microglia $\left(5 \times 10^{5}\right.$ cells $/ 60 \mathrm{~mm}$ dish) were treated with LPS $(0.1 \mu \mathrm{g} / \mathrm{mL})$ in the absence or presence of test compounds. After $20 \mathrm{~h}$ treatment, cells were lysed with cell lysis buffer (Cell Signaling Technologies, Beverly, MA, USA) and centrifuged at $4{ }^{\circ} \mathrm{C}$. Supernatant were collected and protein concentrations were determined by the Bradford method. For preparation of cytosol and nuclear extracts, cells were treated with test compounds for $30 \mathrm{~min}$ prior to the stimulation with $0.1 \mu \mathrm{g} / \mathrm{mL}$ LPS. Following $15 \mathrm{~min}$ treatment of LPS, cells were collected by using NE-PER nuclear and cytoplasmic extraction reagents according to the manufacturer's instructions (Pierce Biotechnology, Rockford, IL, USA). For immunoblot analysis, antibodies against iNOS, COX-2, I- $\kappa \mathrm{B} \alpha$ and p65 were obtained from BD Biosciences (Franklin Lakes, NJ, USA), Cayman Chemical Company and Santa Cruz Biotechnology (Rockford, IL, USA), respectively.

\subsection{Reverse Transcription and Polymerase Chain Reaction (RT-PCR) Analysis}

BV-2 microglia ( $5 \times 10^{5}$ cells $/ 60 \mathrm{~mm}$ dish) were incubated with or without test compounds in presence of LPS $(0.1 \mu \mathrm{g} / \mathrm{mL})$. Total RNA was isolated from the cells by TRIzol (Life Technologies) in accordance with the manufacturer's instructions, and then reverse transcribed into cDNA by using reverse transcriptase (Life Technologies). The cDNA amplification was carried out to detect the target genes (iNOS, COX-2, and $\beta$-actin) by using a recombinant Taq polymerase (Promega, Madison, WI, USA).

\subsection{Statistical Anaylsis}

The results were expressed as mean \pm S.D. of three experiments, and statistical analysis was performed using one way analysis of variance (ANOVA) and Student's $t$-test. A $p$ value of $<0.05$ was regarded as significantly different.

Supplementary Materials: The supplementary materials are available online. ${ }^{1} \mathrm{H}-\mathrm{NMR},{ }^{13} \mathrm{C}-\mathrm{NMR}, \mathrm{COSY}$, HSQC and HMBC spectra of compounds 1, 2 and 3 are available as supporting information.

Acknowledgments: This study was supported by the National Research Foundation of Korea (NRF) grant funded by the Korea government (No. 2011-0030074 and No. 2010-0009582)

Author Contributions: Do Hee Kim, Hwa Li, Yeong Eun Han and Ji Hye Jeong performed the experiments; Hwa Jin Lee analyzed the data and contributed to manuscript preparation; Jae-Ha Ryu designed the whole experiments, analyzed the data and wrote the paper.

Conflicts of Interest: The authors declare no conflict of interest.

\section{References}

1. Dheen, S.T.; Kaur, C.; Ling, E.A. Microglial activation and its implications in the brain diseases. Curr. Med. Chem. 2007, 14, 1189-1197. [CrossRef] [PubMed]

2. Calabrese, V.; Boyd-Kimball, D.; Scapagnini, G.; Butterfield, D.A. Nitric oxide and cellular stress response in brain aging and neurodegenerative disorders: The role of vitagenes. In Vivo 2004, 18, 245-267. [PubMed]

3. Blaylock, R.L. Parkinson's disease: Microglial/macrophage-induced immunoexcitotoxicity as a central mechanism of neurodegeneration. Surg. Neurol. Int. 2017, 8, 65. [CrossRef] [PubMed]

4. Forstermann, U.; Schmidt, H.H.; Pollock, J.S.; Sheng, H.; Mitchell, J.A.; Warner, T.D.; Nakane, M.; Murad, F. Isoforms of nitric oxide synthase. Characterization and purification from different cell types. Biochem. Pharmacol. 1991, 42, 1849-1857. [CrossRef]

5. Whittle, B.J. Nitric oxide in physiology and pathology. Histochem. J. 1995, 27, 727-737. [CrossRef] [PubMed]

6. Gebicke-Haerter, P.J. Microglia in neurodegeneration: Molecular aspects. Microsc. Res. Tech. 2001, 54, 47-58. [CrossRef] [PubMed]

7. Ivanov, A.I.; Romanovsky, A.A. Prostaglandin E2 as a mediator of fever: Synthesis and catabolism. Front. Biosci. 2004, 9, 1977-1993. [CrossRef] [PubMed] 
8. Sales, K.J.; Jabbour, H.N. Cyclooxygenase enzymes and prostaglandins in pathology of the endometrium. Reproduction 2003, 126, 559-567. [CrossRef] [PubMed]

9. Johnson, R.W. Feeding the beast: Can microglia in the senesent brain be regulated by diet? Brain Behav. Immun. 2015, 43, 1-8. [CrossRef] [PubMed]

10. Wang, Y.; Plastina, P.; Vincken, J.P.; Jansen, R.; Balvers, M.; Ten Klooster, J.P.; Gruppen, H.; Witkamp, R.; Meijerink, J. N-docosahexaenoyl dopamine, an endocannabinoid-like conjugate of dopamine and the n-3 fatty acid docosahexaenoic acid, attenuates lipopolysaccharide-induced activation of microglia and macrophages via COX-2. ACS Chem. Neurosci. 2017, 8, 548-557. [CrossRef] [PubMed]

11. Chopra, B.; Dhingra, A.K.; Dhar, K.L. Psoralea corylifolia L. (Buguchi)—Folklore to modern evidence: Review. Fitoterapia 2013, 90, 44-56. [CrossRef] [PubMed]

12. Lee, M.H.; Kim, J.Y.; Ryu, J.H. Prenylflavones from Psoralea corylifolia inhibit nitric oxide synthase expression through the inhibition of I-kappaB-alpha degradation in activated microglial cells. Biol. Pharm. Bull. 2005, 28, 2253-2257. [CrossRef] [PubMed]

13. Bronikowska, J.; Szliszka, E.; Jaworska, D.; Czuba, Z.P.; Krol, W. The coumarin psoralidin enhances anticancer effect of tumor necrosis factor-related apoptosis-inducing ligand (TRAIL). Molecules 2012, 17, 6449-6464. [CrossRef] [PubMed]

14. Srinivasan, S.; Sarada, D.V. Antifungal activity of phenyl derivative of pyranocoumarin from Psoralea corylifolia L. seeds by inhibition of acetylation activity of trichothecene 3-o-acetyltransferase (Tri101). J. Biomed. Biotechnol. 2012, 2012, 310850. [CrossRef] [PubMed]

15. Wu, C.Z.; Hong, S.S.; Cai, X.F.; Dat, N.T.; Nan, J.X.; Hwang, B.Y.; Lee, J.J.; Lee, D. Hypoxia-inducible factor-1 and nuclear factor-kappaB inhibitory meroterpene analogues of bakuchiol, a constituent of the seeds of Psoralea corylifolia. Bioorg. Med. Chem. Lett. 2008, 18, 2619-2623. [CrossRef] [PubMed]

16. Xin, D.; Wang, H.; Yang, J.; Su, Y.F.; Fan, G.W.; Wang, Y.F.; Zhu, Y.; Gao, X.M. Phytoestrogens from Psoralea corylifolia reveal estrogen receptor-subtype selectivity. Phytomedicine 2010, 17, 126-131. [CrossRef] [PubMed]

17. Park, J.; Kim, D.H.; Ahn, H.N.; Song, Y.S.; Lee, Y.J.; Ryu, J.H. Activation of Estrogen Receptor by Bavachin from Psoralea corylifolia. Biomol. Ther. 2012, 20, 183-188. [CrossRef] [PubMed]

18. Pistelli, L.; Spera, K.; Flamini, G.; Mele, S.; Morelli, I. Isoflavonoids and chalcones from Anthyllis hermanniae. Phytochemistry 1996, 42, 1455-1458. [CrossRef]

19. Haraguchi, H.; Inoue, J.; Tamura, Y.; Mizutani, K. Antioxidative components of Psoralea corylifolia (Leguminosae). Phytother. Res. 2002, 16, 539-544. [CrossRef] [PubMed]

20. Kuete, V.; Sandjo, L.P. Isobavachalcone: An overview. Chin. J. Integr. Med. 2012, 18, 543-547. [CrossRef] [PubMed]

21. Gupta, B.K.; Gupta, G.K.; Dhar, K.L.; Atal, C.K. A C-formylated chalcone from Psoralea corylifolia. Phytochemistry 1980, 19, 2034-2035. [CrossRef]

22. Thoshio, F.; Junko, N.; Taro, N. Five isoprenoid-substituted flavonoids from Glycyrrhiza eurycarpa. Phytochemistry 1993, 35, 515-519.

23. Beckman, J.S.; Beckman, T.W.; Chen, J.; Marshall, P.A.; Freeman, B.A. Apparent hydroxyl radical production by peroxynitrite: Implications for endothelial injury from nitric oxide and superoxide. Proc. Natl. Acad. Sci. USA 1990, 87, 1620-1624. [CrossRef] [PubMed]

24. Guix, F.X.; Wahle, T.; Vennekens, K.; Snellinx, A.; Chavez-Gutierrez, L.; Ill-Raga, G.; Ramos-Fernandez, E.; Guardia-Laguarta, C.; Lleo, A.; Arimon, M.; Berezovska, O.; et al. Modification of gamma-secretase by nitrosative stress links neuronal ageing to sporadic Alzheimer's disease. EMBO Mol. Med. 2012, 4, 660-673. [CrossRef] [PubMed]

25. Lee, M.H.; Kim, J.Y.; Yoon, J.H.; Lim, H.J.; Kim, T.H.; Jin, C.; Kwak, W.J.; Han, C.K.; Ryu, J.H. Inhibition of nitric oxide synthase expression in activated microglia and peroxynitrite scavenging activity by Opuntia ficus indica var. saboten. Phytother. Res. 2006, 20, 742-747. [CrossRef] [PubMed]

26. Ahn, K.S.; Aggarwal, B.B. Transcription factor NF-kappaB: A sensor for smoke and stress signals. Ann. N. Y. Acad. Sci. 2005, 1056, 218-233. [CrossRef] [PubMed]

27. Yamamoto, M.; Takeda, K. Role of nuclear IkappaB proteins in the regulation of host immune responses. J. Infect. Chemother. 2008, 14, 265-269. [CrossRef] [PubMed]

28. Wan, F.; Lenardo, M.J. The nuclear signaling of NF-kappaB: Current knowledge, new insights, and future perspectives. Cell Res. 2010, 20, 24-33. [CrossRef] [PubMed] 
29. Jing, H.; Wang, S.; Wang, M.; Fu, W.; Zhang, C.; Xu, D. Isobavachalcone attenuates MPTP-induced Parkinson's disease in mice by inhibition of microglial activation through NF-kB pathway. PLoS ONE 2017, 12, e0169560. [CrossRef] [PubMed]

30. Shin, H.J.; Shon, D.H.; Youn, H.S. Isobavachalcone suppresses expression of inducible nitric oxide synthase induced by Toll-like receptor agonists. Int. Immunopharmacol. 2013, 15, 38-41. [CrossRef] [PubMed]

Sample Availability: Samples of the compounds are not available from the authors.

(C) 2018 by the authors. Licensee MDPI, Basel, Switzerland. This article is an open access article distributed under the terms and conditions of the Creative Commons Attribution (CC BY) license (http://creativecommons.org/licenses/by/4.0/). 